\title{
SYNERGISTIC ACTION OF STARCH AND HONEY AGAINST CANDIDA ALBICANS IN CORRELATION WITH DIASTASE NUMBER
}

\author{
Laïd Boukraa; Hama Benbarek; Ahmed Moussa \\ Department of Veterinary Sciences Faculty of Agro-Veterinary Sciences Ibn-Khaldoun University \\ of Tiaret Algeria
}

Submitted: July 24, 2007; Returned to authors for corrections: November 04, 2007; Approved: January 18, 2008.

\begin{abstract}
To evaluate the synergistic action of starch on the antifungal activity of honey, a comparative method of adding honey with and without starch to culture media was used. Candida albicans has been used to determine the minimum inhibitory concentration (MIC) of five varieties of honey. In a second step, lower concentrations of honey than the MIC were incubated with a set of concentrations of starch added to media to determine the minimum synergistic inhibitory concentration (MSIC). The MIC for the five varieties of honey without starch against $C$. albicans ranged between $40 \%$ and $45 \%(\mathrm{v} / \mathrm{v})$. When starch was incubated with honey and then added to media, a MIC drop has been noticed with each variety. It ranged between $7 \%$ and $25 \%$. A negative correlation has been established between the MIC drop and the diastase number (DN).
\end{abstract}

Key words: Antifungal, Honey, Starch, Diastase Number, Candida albicans.

\section{INTRODUCTION}

The majority of human mycoses are caused by opportunistic fungi (6). Opportunistic pathogens produce illness by taking advantage of debilitated or immuno-compromised hosts (7). $C$. albicans is a fungus which can grow on warm and moist surfaces and cause superficial diseases such as oral and vaginal thrush and chronic mucocutaneous candidiasis (10). In ophthalmology, rubbery concretions occur in the presence of infections due to species of Candida. Honey is a natural product that is used for its antifungal activity (5). Its antimicrobial properties have been extensively reviewed (8). Honey has a potent antibacterial activity and is very effective in clearing infection in wounds and protecting them from becoming infected (1). Unlike honey, no inhibitory action has been allocated to starch. In contrary, it is known that starch could be incorporated into microbial media to stimulate their growth (15). One of the characteristics that set honey apart from all other sweetening agents is the presence of enzymes. Some of the most important honey enzymes are invertase, diastase, and glucose oxidase. Those most prominent are added by the bee during the conversion of nectar to honey. In some countries, the specification of enzymes is a binding legal indicator (3). The diastase content varies according to floral source, long storage periods and exposure to high temperatures (14). Legislation has set a minimum level for diastase activity; it should not be less than $8 \mathrm{DN}$ units, where $1 \mathrm{DN}$ unit hydrolyses $1 \mathrm{~mL}$ of $1 \%$ starch using $1 \mathrm{~g}$ of honey for 1 hour at $37^{\circ} \mathrm{C}(2)$. The $\alpha$-amylase splits the starch chain randomly, producing dextrin, and the $\beta$-amylase splits the reducing sugar maltose from the ends of the starch chain (12). But no starch is found in honey. Therefore, it is expected that adding starch, which is the substrate of the diastase, to honey will subsequently increase the antifungal effect of honey. This study was carried out to evaluate the antifungal properties of honey and starch when used jointly to manage superficial mycoses. On the other hand we are exploring a novel concept that starch, normally a microbial nutrient, may actually enhance the antifungal properties of honey. A possible correlation between the additive action of honey and starch and the diastase number of honey is to be examined.

*Corresponding Author. Mailing address: Department of Veterinary Sciences Faculty of Agro-Veterinary Sciences Ibn-Khaldoun University of Tiaret Algeria, Address: BP108 Tiaret Université 14010 Tiaret Algeria. Tel.: (213) 757773 35. Email: laid_bouk@hotmail.com 


\section{MATERIALAND METHODS}

\section{Honey samples}

Five honey varieties (V1 to V5) from different botanic origins were analysed. Samples were obtained directly from beekeepers in different regions of Algeria during the year 2005. The Diastase Number (DN) of each variety was measured according to Phadebas method $(4,11)$.

\section{Fungal strain and inoculums standardization}

Candida albicans has been kindly provided by the "Institut Pasteur d'Alger". It was maintained by subculture in specific media (YPGA: Yeast Peptone Glucose Agar). The inoculum suspensions of $C$. albicans was obtained by taking five colonies ( $>1 \mathrm{~mm}$ diameter) from 24-h-old cultures grown on YPGA. The colonies were suspended in $5 \mathrm{~mL}$ of sterile saline $(0.85 \% \mathrm{NaCl})$. The inoculum suspensions were shaken for $15 \mathrm{~s}$ and the density was adjusted to the turbidity of a 0.5 McFarland Standard (equivalent to $1-5 \times 10^{6} \mathrm{cfu} / \mathrm{mL}$ ) with sterile saline. The suspensions were diluted 1:1000 in RPMI 1640 to give a final inoculum suspension equivalent to $0.5-2.5 \times 10^{3}$ $\mathrm{cfu} / \mathrm{mL}$

\section{Minimum inhibitory concentration measurement (MIC)}

Concentrations of honey between $40 \%$ and $50 \%(\mathrm{v} / \mathrm{v})$ were incorporated into media to test their efficiency against $C$. albicans. The final volume of honey and media in each plate was $5 \mathrm{~mL}$. The plates were inoculated and incubated at $37^{\circ} \mathrm{C}$ for $48 \mathrm{~h}$. The MIC (Minimum Inhibitory Concentration) was determined by finding the plates with the lowest concentration of honey on which the strain would not grow. All MIC values are expressed in $\%(\mathrm{v} / \mathrm{v})$.

In a second step and to evaluate the effect of starch on the antifungal action of honey, a 10\% starch solution was prepared using sterile water. Different volumes from the stock solution were added to a range of honey concentrations lower than the MIC. The same volume of starch solution that has given inhibition with honey is added alone to media as control to check whether or not starch alone has an inhibition effect against C. albicans. An equivalent volume of water was added to honey instead of starch solution to confirm that inhibition is not due to the dilution of honey. The final volume in each plate was 5 $\mathrm{mL}$. Starch content in media ranged between $0.3 \%$ and $2.8 \%$ $(\mathrm{w} / \mathrm{v})$. Honey and starch as well as honey and water were incubated for 24 hours at $37^{\circ} \mathrm{C}$ before being incorporated into media. This will allow the diastase present in honey to act against starch. Plates were inoculated and incubated at $37^{\circ} \mathrm{C}$ for 48 hours. All inoculations were carried out in triplicates.

\section{Statistical analysis}

Isobolographic analysis was carried out to measure the additive action of honey and starch against fungi. Statistica ${ }^{\circledR}$ software was used to determine whether there is a correlation between the additive action and the $\mathrm{DN}$.

\section{RESULTS}

Table 1 represents the Diastase Number (DN) of the five varieties of honey. The DN ranged between 13.1 and 26.1 which are in the interval of international standards (12). All varieties of honey were effective against $C$. albicans. Without starch, the MIC of the five varieties ranged between $40 \%(\mathrm{v} / \mathrm{v})$ and $45 \%$ $(\mathrm{v} / \mathrm{v})$ (Table 2). Effectiveness against $C$. albicans varies widely within honey varieties. When starch was incubated with honey and added to media, the MIC of the five varieties ranged between $30 \%(\mathrm{v} / \mathrm{v})$ and $39 \%(\mathrm{v} / \mathrm{v})$ which represents a MIC drop between $7 \%$ and $25 \%$. The inhibitory action was seen neither in the media containing starch only nor in media with honey and water. Statistically, additive effect is noticed between starch and all varieties of honey. This additive effect has negative correlation with DN.

Table 1. DN values of the five varieties of honey.

\begin{tabular}{cc}
\hline Honey variety & Diastase Number (DN) \\
\hline V1 & 15.2 \\
V2 & 26.1 \\
V3 & 13.1 \\
V4 & 16.6 \\
V5 & 14.6 \\
\hline
\end{tabular}

Table 2. MIC values of the five varieties of honey against $C$. albicans.

\begin{tabular}{cccc}
\hline \multirow{2}{*}{$\begin{array}{c}\text { Honey } \\
\text { Varieties }\end{array}$} & $\begin{array}{c}\text { MIC \% (v/v) } \\
\text { honey only }\end{array}$ & \multicolumn{2}{c}{$\begin{array}{c}\text { MIC \% (v/v) } \\
\text { honey and starch }\end{array}$} \\
\cline { 3 - 4 } & & $\begin{array}{c}\text { Honey content } \\
\text { in media \%(v/v) }\end{array}$ & $\begin{array}{c}\text { Starch content } \\
\text { in media (w/v) }\end{array}$ \\
\hline V1 & 42 & 34 & 2.2 \\
V2 & 42 & 39 & 2.4 \\
V3 & 43 & 34 & 2.8 \\
V4 & 45 & 36 & 2.6 \\
V5 & 40 & 30 & 2.6 \\
\hline
\end{tabular}

\section{DISCUSSION}

It has been demonstrated in many studies that honey has antibacterial effects, attributed to its high osmolarity, low $\mathrm{pH}$, hydrogen peroxide content and content of other, uncharacterised compounds (9). The low water activity of honey 
is inhibitory to the growth of the majority of bacteria but this is not the only explanation for its antimicrobial activity. Molan (8) has studied sugar syrups of the same water activity as honey and found them to be less effective than honey at inhibiting microbial growth in vitro. Adding starch to honey has shown a significant decrease in the MIC for the five varieties of honey against the tested strains. The Figs. 1 to 5 show an additive action of starch and honey against the tested strain which is represented by isobolograms. Figures show an overadditive effect of starch and all varieties of honey against $C$. albicans. The isobolograms illustrate several different dose combinations

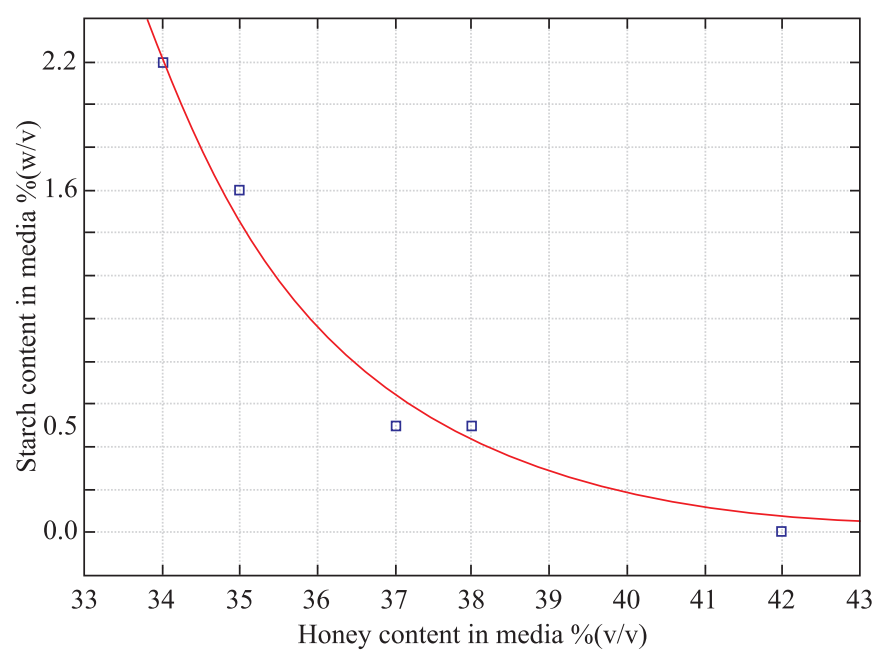

Figure 1. Isobologram representing overadditive effect of starch and variety 1 of honey against $C$. albicans.

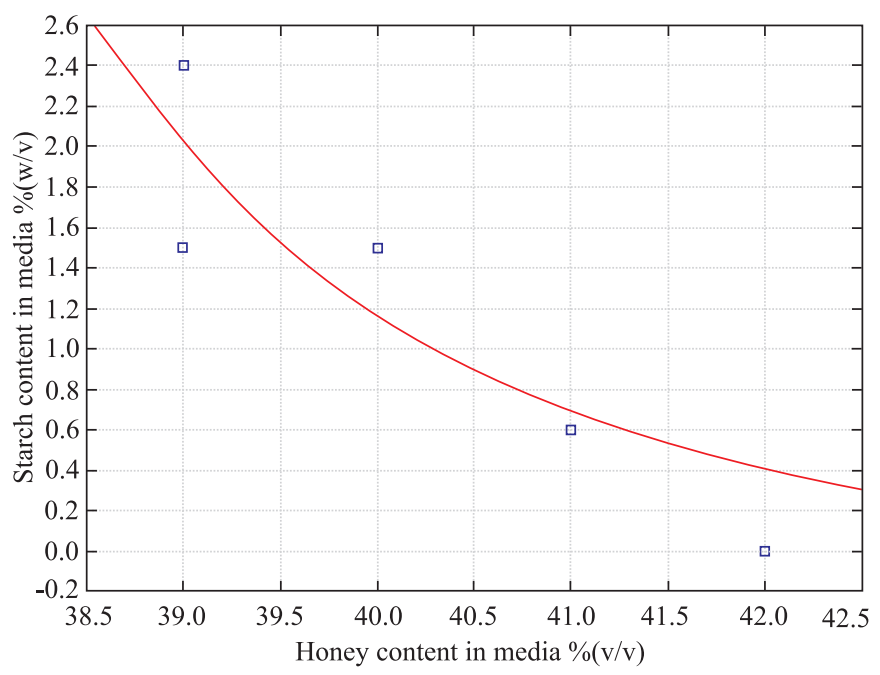

Figure 2. Isobologram representing overadditive effect of starch and variety 2 of honey against $C$. albicans.

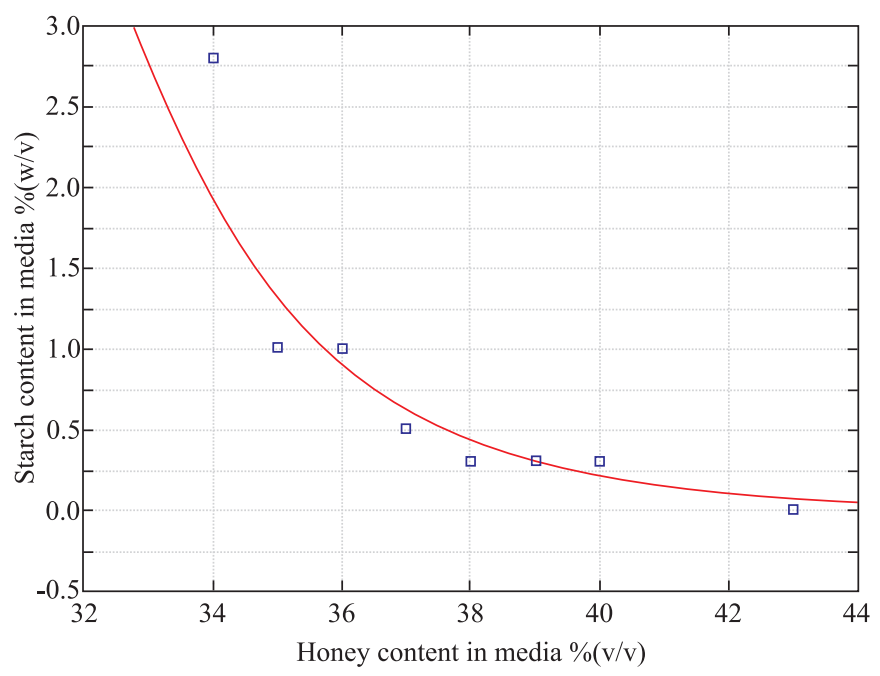

Figure 3. Isobologram representing overadditive effect of starch and variety 3 of honey against $C$. albicans.

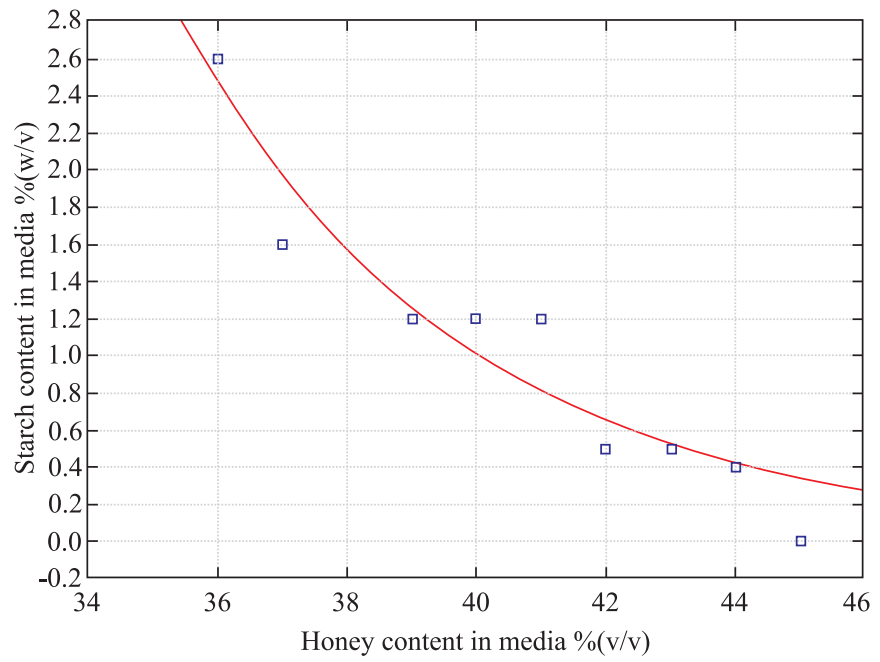

Figure 4. Isobologram representing overadditive effect of starch and variety 4 of honey against $C$. albicans.

that attain the specified effect level. The overaditive action is also called synergism (13).The inhibitory action was seen neither in the media containing starch only nor in media with honey and water with the corresponding MIC. A significant negative correlation $(\mathrm{R}=-0.936)$ has been noticed between $\mathrm{DN}$ and the MIC drop when using starch with the five varieties of honey (Fig. 6). Amylases present in honey were expected to split starch chains to randomly produce dextrin and maltose and probably increase the osmotic effect in the media by increasing the amount of sugars and consequently increase the antifungal activity. But the amount of the amylase in honey is not in positive 


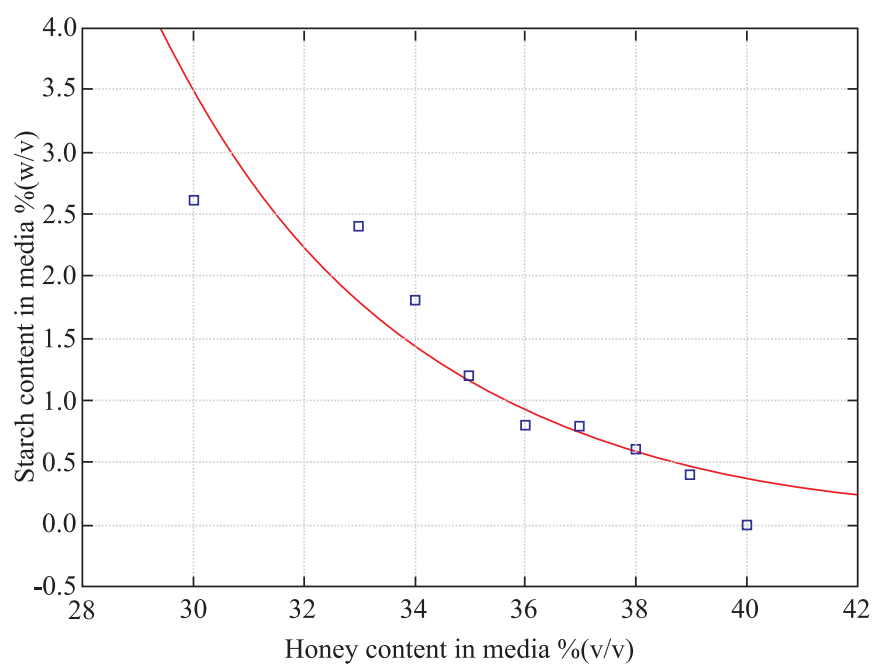

Figure 5. Isobologram representing overadditive effect of starch and variety 5 of honey against $C$. albicans.

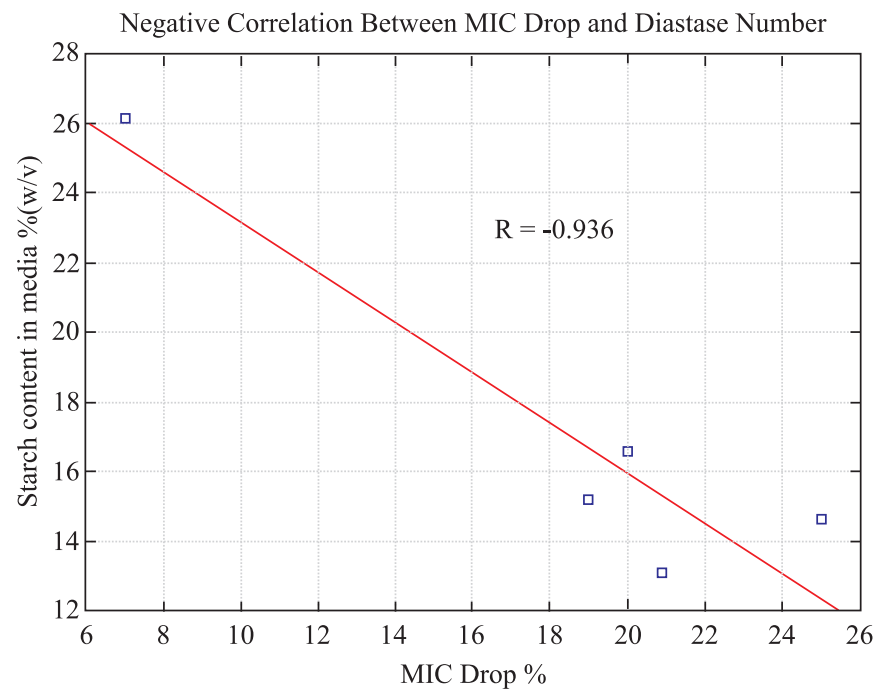

Figure 6. Negative correlation between the MIC drop and DN of the five varieties of honey.

correlation with the relative potency of starch and honey. As a paradox, the variety 3 (V3) which has the lowest DN (13.1) has shown a highest MIC drop (20.5) and V2 with the highest DN has shown the lowest MIC drop (7\%). That means that other unknown factors may play a role in this combined potency. Further researches are needed to elucidate and optimize the effective combination of these natural products in clinical practice. The current prevalence of antibiotic-resistant microbial species has led to a re-evaluation of the therapeutic use of ancient remedies, including honey and starch. Both natural products have no adverse effects on tissues, so they can be safely used on wounds and inserted into cavities and sinuses to clear infection.

\section{RESUMO}

\section{Ação sinergística de amido e mel sobre Cândida albicans em relação ao índice de diastase}

Para avaliar a ação sinergística do amido na atividade antifúngica do mel, utilizou-se um método comparativo de adição ou não de mel ao meio de cultura com e sem amido. Cândida albicans foi utilizada para determinar a Concentração Inibitória Mínima (CIM) de cinco variedades de mel. Na etapa seguinte, determinou-se a Concentração Inibitória Sinergística Mínima (CISM) empregando-se méis em concentração abaixo da CIM incubados com amido em diferentes concentrações.

Palavras-chave: Antifúngios, mel, amido, número de diástase, Candida albicans.

\section{REFERENCES}

1. Allen, K.L. (2000). The potential for using honey to treat wounds infected with MRSA and VRE, First World Wound Healing Congress, 12-13 September. Melbourne. Australia.

2. AOAC. (1999). In Methods of Analysis. Association of Official Analytical Chemists, (15th ed.). Washington, DC.

3. Bogdanov, S.; Rieder, K.; Riëg, M.G. (1987). Neue Qualitätskriterien bei Honiguntersuchungen. Apidologie, (18): 267-278.

4. Bogdanov, S.; Martin, P.; Lüllmann, C. (1999). Harmonised methods of the European Honey Commission. Apidologie, 1-59.

5. Irish, J.; Carter, D.A.; Shokohi, T.; Blair, E.S. (2006). Honey has an antifungal effect against Candida species. Medical Mycology, (44) 289-291.

6. Kwon-Chung, K.J.; Bennett, J.E. (1992) Medical mycology. Lea \& Febiger, Philadelphia, Pa.

7. McGinnis, M.R.; Sigler, L.; Rinaldi, M.G. (1999). Some medically important fungi and their common synonyms and names of uncertain application. Clin. Infect. Dis., (29): 728-730.

8. Molan, P. (1992).The antimicrobial activity of honey. Bee world, (73): 5-28.

9. Molan, P.C. (1995). The antibacterial properties of honey. Chem. in NZ 10-14.

10. Molero, G.; Díez-Orejas, R.; Navarro-García, F.; Monteoliva, L.; Pla, J.; Gil, C.; Sánchez-Pérez, M.; Nombela, C. (1998).Candida albicans: genetics, dimorphism and pathogenicity. Internatl Microbiol., (1): 95-106.

11. Persano Oddo, L.; Pulcini, P. (1999) A scientific note on the Phadebas method for honeys with low enzyme content. Apidologie, (30): 347-348.

12. Persano Oddo, L.; Piazza, M.G.; Pulcini, P. (1999). Invertase activity in honey. Apidologie, (30): 57-65.

13. Tallarida, J.R. (2001). Drug Synergism: Its Detection and Applications. Pharmacology, (298): 365-872.

14. White, J.W. (1992). Quality Evaluation of Honey: Role of HMF and Diastase Assay. Am. Bee J., (132): 737-743, 792-794.

15. Zangrando Figueira, E.L.; Hirooka, E.Y. (2000). Culture Medium for Amylase Production by Toxigenic Fungi. Braz. Arch. Biol. Technol., (43): 461-467. 